\title{
AS FORMAS MODERNAS DOS DIREITOS HUMANOS EM FRANCISCO DE VITORIA
}

Pedro D. B. Brocco ${ }^{I}$

\section{Resumo}

O trabalho procurará mostrar a fundamentação moral e jurídica na obra de Francisco de Vitoria (1486-1546) para o que modernamente começa a ser chamado de "direitos humanos". Com efeito, a obra de Vitoria, ao contrário de ter fornecido um esquema para uma eventual dominação, em verdade procurou congregar os povos americanos em torno da ética cristã, tendo um caráter eminentemente universalista. O argumento será construído tendo como base as noções de poder civil, de liberdade e de livre circulação e comunicação. Ao articularmos esses elementos, procuraremos mostrar que Vitoria foi capaz de defender uma concepção de ética e de Direito Internacional de vanguarda para a época, questionando diretamente a forma como se dava a colonização espanhola na América.

Palavras-chave: Renascimento. Humanismo. Direitos humanos. América colonial. Francisco de Vitoria.

\section{INTRODUÇÃO}

O dominicano espanhol Francisco de Vitoria (1486-1546), teólogo e jurista que exerce a docência na França e na Espanha no século XVI, é uma das figuras mais importantes não apenas da Escola de Salamanca, mas do Renascimento e do humanismo. Renovador da teologia e promotor da nova escolástica vigente durante os séculos XVI e XVII, influencia inúmeros estudiosos e os desdobramentos institucionais de suas ações, na Europa e no Novo Mundo. Sua obra contém os princípios de direito natural que formarão a base do que lhe é creditado como a fundação do Direito Internacional: muito antes do jusnaturalismo racionalista atribuído a Hugo Grócio (1583-1645) com sua obra De iure belli ac pacis, de 1625, e de Samuel Pufendorf, autores muito citados em estudos de Direito Internacional e Filosofia do Direito. A afirmação tem procedência pois, não obstante tenham Grócio e Pufendorf articulado conceitos fundamentais do Direito natural, do Direito público e do Direito internacional, que então se gestava, após um breve exame podemos encontrar quase a totalidade dos tópicos levantados anteriormente por Francisco de Vitoria. Há no obscurecimento da obra Vitoria na Europa do século XVII uma tentativa de secularizar a maioria dos conceitos com os quais o dominicano construiu sua teoria, de

\footnotetext{
${ }^{1}$ Doutorando em Ciências Jurídicas e Sociais pelo Programa de Pós-Graduação em Sociologia e Direito da Universidade Federal Fluminense (PPGSD-UFF).E-mail: pedrodbb@gmail.com
} 
corte rigorosamente tomista ${ }^{2}$.

Vitoria nasceu em Burgos e ingressou no Convento de São Paulo, que a Ordem dominicana possuía na cidade, e ali passou seus primeiros anos de formação. Foi enviado por seus superiores para o convento de Santiago de Paris, provavelmente em 1508, para completar seus estudos em Humanidades e Artes e continuar seus estudos em Teologia. Na Universidade de Paris faz amizade com os grandes humanistas da época, como Luis Vivès e Erasmo, do qual se conservam algumas cartas que demonstram grande apreço por Vitoria. Além do humanismo, Vitoria conhece em Paris as correntes dominantes do tomismo e do nominalismo, das quais recolhe os melhores ensinamentos para a sua formação e seu espírito. Provenientes das duas correntes são os mestres de Vitoria na época: do lado tomista, podemos citar Pedro de Bruxelas ou Peter Crockaert, filósofo flamengo que inicialmente fora pupilo de John Mair e seguidor de Guilherme de Ockham, tendo se juntado depois à Ordem dominicana e aos estudos tomistas. Crockaert ensinou na Universidade de Paris e é conhecido por alguns comentários a Aristóteles e Santo Tomás de Aquino. Dele parece ter vindo uma das influências mestras de Vitoria. Além de Crockaert, houve alguns filósofos nominalistas, como Juan Celaya, Jacob Almain e John Mair ou Major.

Sobre o peculiar filósofo escocês John Major (1469-1550), julgo caber um breve comentário sobre sua influência sobre Vitoria e a Escola de Salamanca. Crê-se que foi John Major o primeiro filósofo a se manifestar sobre a licitude da conquista das terras do Novo Mundo, e isto unicamente devido às exigências de sua condição de docente da Universidade de Paris. Major seguirá um plano de estudos presentes em seus Comentários ao Livro das sentenças de Pedro Lombardo. Neste momento, provavelmente mirando as Bulas alexandrinas, exprimirá que nem o Papa e nem o imperador são senhores do universo nem possuem direitos sobre as terras do Novo Mundo, por isso não podem concedê-las a ninguém ${ }^{3}$. Mas John Major previa duas exceções a essa afirmação: i) no caso de uma oposição à pregação e ocorrendo uma perseguição dos que se tenham convertido, e ii) por incapacidade dos índios de governarem a si mesmos, por causa de sua barbárie, da qual resultaria necessitarem da tutela dos europeus por serem servos por natureza, seguindo Aristóteles. Nestes dois casos, Major segue Duns Escoto ao aceitar que o Papa poderia conceder a algum rei cristão a missão de conquistar por armas o território de povos infiéis ${ }^{4}$. Mauricio Beuchot localizará na obra de John Major o primeiro plano teológico-jurídico da conquista da América 5 . Em 1510, Major discutiu questões legais e morais oriundas da conquista espanhola da América.

\footnotetext{
${ }^{2}$ Neste sentido, estamos de acordo com Schmitt, quando afirma que todos os conceitos formadores da moderna teoria do Estado são conceitos teológicos secularizados. Cf. SCHMITT, Carl. Teología política. Cuatro ensayos sobre la soberanía. Buenos Aires: Struhart \& Cía, s.d., p. 57.

${ }^{3}$ BEUCHOT, Mauricio. La polémica de la guerra de Conquista en relación con México, pp. 147-156. In: BATAILLON, G.; BIENVENU, G.; GOMEZ, A. V. (Org.). Las teorías de la guerra justa en siglo XVI y sus expresiones contemporáneas. México D. F.: Centro de estudios mexicanos y centroamericanos, 1998.

${ }^{4}$ Idem, ibidem.

${ }^{5}$ BEUCHOT, Mauricio. "El primer planteamiento teológico-jurídico sobre la conquista de América: John Mair". Ciencia tomista. Salamanca, 1976, núm. 103, pp. 213-230.
} 
Argumentou que os nativos possuíam direitos políticos e de propriedade que não poderiam ser invadidos e ignorados, ao menos não sem compensações, pelos espanhóis.

Notemos que Major se manifesta publicamente sobre tais questões em seu ensino, na Universidade de Paris, antes mesmo do primeiro sermão conhecido a favor da dignidade dos índios e admoestatório com respeito aos colonizadores espanhóis, proferido pelo Frei Antonio Montesinos, em La Hispaniola, em 1511.

Além disso, John Major foi um grande estudioso de lógica e das estruturas da linguagem falada, escrita e mental. Abarcou uma série de questões desde a perspectiva nominalista, e que certamente influenciou o empirismo insular e europeu de modo geral. Em sua filosofia moral, destaca-se o foco na casuística, isto é, uma abordagem a respeito da complexidade de determinados casos individuais, também segundo o influxo do nominalismo. Daí creio possamos entrever o riquíssimo caldo cultural vivificador do humanismo renascentista e o aporte teórico de dois grandes influenciadores de Francisco de Vitoria, que se ligarão a Tomás de Aquino, sua grande influência: Peter Crockaert e John Major, na Universidade de Paris. Assim, Vitoria forma sua teoria tendo em vista a orientação prática da teologia e o interesse por problemas humanos e temas morais e jurídicos ${ }^{6}$.

Ainda que debruçado sobre temas morais e jurídicos, entretanto, Vitoria não deixou de ser teólogo. Suas atividades estavam ligadas, além da Universidade de Salamanca, à sua ordem religiosa e à hierarquia da Igreja. Ainda não houvera a separação, que se produziria ao longo do século XVI, entre a teologia e a ciência jurídica. No entanto, devemos ver nele também um grande e irreprimível influenciador e articulador das democracias modernas, ao lançar as bases jurídicas e morais da Contrarreforma e do arranjo das colônias. Nesse momento, inevitavelmente, Vitoria reformula doutrinas cuja eficácia havia assegurado a ocupação das terras americanas sob a alegação de "justos títulos", arrimadas na crença de que o Papa seria o mais alto soberano do orbe, competente para assegurar a validade da ocupação europeia das terras americanas recém-descobertas e por descobrir. Examinaremos algumas das teses atacadas por Vitoria, bem como seus argumentos, em uma análise de algumas de suas relecciones.

Há que se reconhecer também que Vitoria estava preocupado com questões práticas envolvendo a Coroa espanhola na primeira metade do século XVI: preocupou-se com, sobretudo, elaborar um sistema justo de colonização das terras recém-descobertas no Novo Mundo?.

Ainda assim, e, quiçá, por ter se preocupado com um sistema universal que comportasse uma antropologia de cariz universalista, Vitoria contribui com diversos e importantes aportes para o Direito público interno e para o Direito eclesiástico. Mestre respeitadíssimo, foi seguido por vários discípulos e por inúmeras gerações de teólogos e juristas que formaram o movimento que conhecemos por Escola de Salamanca.

${ }^{6}$ DELGADO, Luis Frayle, Estudio Preliminar: In VITORIA, Francisco de. Sobre el poder civil, Sobre los índios, Sobre el derecho de la guerra. Madrid: Tecnos, 1998, p. X.

${ }^{7}$ Idem, p. XIV. 
Os embates filosóficos a respeito da teoria do conhecimento que atravessam a Europa entre os séculos XI e XIV podem ser estudados de modo que se possa deles estabelecer modelos para o entendimento sobre a antropologia política que perpassa a colonização do Novo Mundo. Neste cenário, o tomismo aparece como corrente-chave para a compreensão da decolagem de uma cosmovisão ligada ao conhecimento, à política e ao direito. É bem verdade que, à época, não havia fronteiras claras entre esses domínios ou áreas da ação humana, seja prática ou intelectiva (embora, no que pese ao direito, é possível ver por parte do tomismo um intenso diálogo com fontes do direito romano clássico, sobretudo, em Tomás de Aquino, as Institutas de Gaio, além de Cícero). Assim como Santo Tomás, os tomistas que lhe sucederam produziram desde a perspectiva da teologia. A teologia, como ressalta Francisco de Vitoria, é uma ciência totalizante, que pode transitar por e falar sobre todos os domínios da natureza humana. Na introdução de sua exposição de 1528 sobre o poder civil (De potestate civili), Vitória observará que o ofício do teólogo e seu campo de investigação é tão vasto que nenhum tema, nenhuma discussão e nenhum assunto parecem ser alheios à sua profissão e a seu estudo ${ }^{8}$. Era, por isso, um conhecimento radicalmente interdisciplinar e com vocação metaforizante a respeito dos problemas espirituais e sociais a enfrentar.

Entre os séculos XIII e XIV observou-se um debate entre três grandes correntes na Europa: i) o agostinianismo de raiz platônica, portador de grande prestígio e tradição, coagulada na obra de Santo Agostinho; ii) a doutrina tomista, já no século XIII, apoiada em Aristóteles; iii) o nominalismo de Guilherme de Ockham, que retoma as ideias de Roscelino, no século XI, para organizar uma corrente que porá em crise a teoria do conhecimento no século XIV 9 .

A envergadura de Platão para tradição ocidental se constata por sua grande influência sobre Santo Agostinho e os primeiros teólogos católicos da Patrística, como Fílon de Alexandria. Algumas linhas filosóficas de Platão foram assimiladas e sintetizadas pela teologia cristã e pelo que posteriormente foi classificado como "filosofia medieval", embora o homem cristão fosse bastante diferente da "medida grega" do homem ${ }^{10}$. Tais influências foram também decisivas para a formação do que se costumou chamar epistemologia ou teoria do conhecimento.

\section{UMA BREVE ANÁLISE DA RELECTIO DE POTESTATE CIVILI}

A primeira grande exposição de Vitoria na Universidade de Salamanca foi a aula sobre o poder civil (1528). Ainda levará onze anos até a aula sobre os índios, pavimentadora da ética colonial espanhola e talvez sua mais famosa exposição, em 1539; porém, esse primeiro esforço será importantíssimo para a correta compreensão

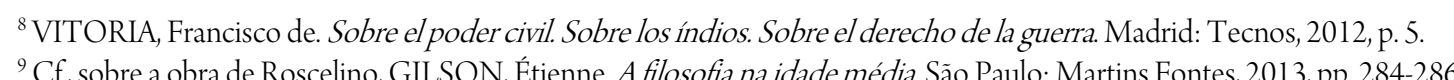
vol.10, nº. 04, Rio de Janeiro, 2017.pp. 2279-2298 
das sociedades autóctones americanas pela teoria vitoriana. Ainda não há aqui uma preocupação por parte de Vitoria de interpolar os argumentos sobre o poder civil com considerações a respeito das colonizações. Arriscarei uma hipótese sobre o De potestate civili: além de configurar um autêntico tratado sobre as leis, é também uma obra que aponta sua artilharia para as Bulas alexandrinas e para o Requerimiento, até então os documentos evocados para embasar a colonização espanhola enquanto "justos títulos".

As Bulas alexandrinas, cujo nome deriva do Papa que as concedeu, Alexandre VI, foram os primeiros documentos jurídicos aplicados na América. A Bula Inter Coetera, de 4 de maio de $1493^{11}$, de Alexandre VI, assegurou a posse das terras descobertas e por descobrir à Coroa de Castela e Leão. No entanto, houve no total cinco documentos relativos às Índias expedidos e assinados pelo Papa Alexandre VI, todos favoráveis à Coroa espanhola.

Entre o retorno de Cristóvão Colombo de sua primeira navegação à América (15-03-1493) e sua segunda viagem (25-09-1493) o corpo diplomático espanhol agiu rapidamente junto à Santa Sé para que fosse assegurada, juridicamente, a posse das terras recém-descobertas. No breve período, portanto, que antecedeu a segunda ida de Colombo às terras americanas, Alexandre VI assina os seguintes documentos: a) primeira Bula Inter Coetera, 03 de maio de 1493; b) a Eximiae devotionis ${ }^{12}, 03$ de maio de 1493; c) a segunda Inter Coetera ${ }^{13}$, 04 de maio de 1493; d) a Piis fidelium ${ }^{14}, 25$ de junho de 1493; e) a Dudum siquidem ${ }^{15}, 25$ de junho de 1493.

Diante da empresa orquestrada que aliou um corpo diplomático célere e a expedição de cinco documentos eclesiásticos, cuja eficácia temporal é incontestável, em um período de pouco mais de um mês, não há que se negar o valor jurídico-político de tais documentos ainda que oriundos de uma autoridade eclesiástica. Antes de se retirar a característica eminentemente jurídica de tais documentos, devemos examinar os fundamentos sobre os quais se construíram o sentimento de validade e eficácia de tais documentos, e em que

\footnotetext{
${ }^{10}$ REALE, Giovanni; ANTISERI, Dario. História da filosofia: patrística e escolástica, v.2. São Paulo: Paulus, 2003, p. 24.

${ }^{11}$ Há duas Bulas Inter Coetera, uma de 3 de maio e outra de 4 de maio de 1493.

${ }^{12}$ Trata-se de um documento que basicamente repete o conteúdo da Bula Inter Coetera, reiterando, porém, que se outorgava a Castela os privilégios, graças, liberdades imunidades e faculdades que já se havia outorgado anteriormente a Portugal. Essa Bula surge com vistas a amainar os previsíveis protestos portugueses à Inter Coetera.

${ }^{13}$ A segunda Inter Coetera ampliava as doações contidas na Inter Coetera do dia anterior: atribuía à Coroa espanhola o domínio integral e exclusivo sobre as terras e povos revelados por Cristóvão Colombo.

${ }^{14}$ Trata-se de Bula que concede amplas faculdades em matéria espiritual ao frade Bernardo Boyl, religioso e diplomata espanhol. Aqui podemos ver que, muito antes de Antonio Vieira, as Coroas ibéricas já se valiam de religiosos com habilidades diplomáticas enviados em missões secretas. Boyl, com efeito, ao final de 1476, era secretário do futuro rei espanhol Fernando II, o Católico, que o envia para negociar com os franceses. Boyl acompanha Colombo em sua segunda viagem à América, em 1493, como missionário e Vicário Apostólico nas Índias Ocidentais, título outorgado pelo Papa Alexandre VI. Regressa à Espanha em 1494 ante a dificuldade de não conseguir se comunicar com os indígenas. Cf. Boyl, Bernardo, na Gran Enciclopedia Aragonesa. Acesso em 26 de agosto de 2015.

${ }^{15}$ Bula que reafirmava a direito castelhano às ilhas e terras firmes achadas e por achar, descobertas e por descobrir, as quais, navegando ou caminhando para o Ocidente ou Meio-dia, estejam quer nas partes ocidentais, meridionais e da Índia. Cf. ANDRADE DA SILVA, Dinair. “Tensões entre Castela e Portugal a propósito dos descobrimentos atlânticos: um estudo das bulas alexandrinas". In Anais Eletrônicos do IV Encontro da ANPHLAC. Salvador, 2000. Acesso em 26 de agosto de 2015.
} 
medida a teoria de Vitoria aponta para uma fundamentação distinta, pois o jurista da Corte de Castela, no limiar do século XVI, diante da situação inusitada e desconhecida da descoberta do Novo Mundo, tinha duas alternativas para responder às questões levantadas pela descoberta: utilizar os modelos e instrumentos que o mundo jurídico medieval oferecia ou trilhar um novo caminho, como fez Vitoria ${ }^{16}$.

O modelo jurídico medieval ao qual nos referimos tem como fundamento a teoria dos dois poderes ou das duas espadas, cuja raiz remonta a Santo Agostinho. Em De Civitate Dei, Agostinho cria a distinção entre os dois amores e as duas cidades, de acordo com a qual a cidade terrena é um tirocínio para a cidade celeste. A comunidade dos fiéis, assim, seria a representante da cidade de Deus que está nos céus. Até o período das Cruzadas, o conceito de Cristandade possuía carga majoritariamente espiritual, designando o conjunto daqueles que se consideravam cristãos e professavam a fé cristã. A partir de determinado momento, quando a Europa se vê ameaçada pelos sarracenos, o Papa João VIII pede ajuda a Bizâncio para a defesa da Cristandade, dando-lhe uma característica mais mundana e secular, ao invés da carga exclusivamente espiritual. Neste sentido, e já dando continuidade à sobreposição entre o poder temporal e o poder espiritual que vimos acontecer durante o reinado de Carlos Magno, a Ecclesia acaba por se confundir, paulatinamente, com a Cristandade e com os poderes seculares, fazendo-se um autêntico Estado, com todos os poderes civis daí derivados, inclusive enfrentando militarmente potências terrenas. Daí derivará uma extensa história, que não será aqui abordada, onde se encontrarão, em uma Itália dividida, os guelfos, partidários do Papa, e os gibelinos, partidários do Imperador do Sacro Império, em uma guerra de sucessão secularíssima, entre os séculos XII e início do XIV, na qual estará envolvido ninguém menos do que Dante Alighieri, que era guelfo.

Dante Alighieri traz, aliás, em seus escritos políticos como a Monarchia, a formulação da teoria dos dois poderes: o poder temporal-secular é um desdobramento de uma autoridade universal celeste, que desce sobre o imperador temporal sem qualquer mediação. Tais teses, aceitas e ventiladas no medievo, seguirão dois caminhos mais ou menos simultâneos: i) sofrerão uma hipertrofia com a utilização, por parte da Igreja e dos Pontífices, da fundamentação segundo a qual estes seriam, enquanto vicários de Cristo e herdeiros do trono de Pedro, os representantes máximos do poder da Cristandade e, neste sentido, estariam acima dos reis e imperadores; e ii) o outro caminho começa a ser trilhado já na Idade Média com a crítica da teoria dos dois poderes e a limitação do poder soberano do Pontífice por autores como Marsílio de Pádua e Guilherme de Ockham. Entre os pensadores medievais que se vincularam à cosmovisão segundo a qual o Pontífice teria tanto autoridade espiritual quanto secular, sendo quanto a esta a autoridade máxima, podemos citar o agostiniano Egídio Romano e Henrique de Susa, apelidado o Ostiense, autor do século XIII para quem Cristo, ao assumir a natureza humana, fora constituído rei do universo. Assim, os príncipes então existentes haviam perdido seus direitos e os transferiram

\footnotetext{
${ }^{16}$ Cf. RUIZ, Rafael. Francisco de Vitoria e os direitos dos índios americanos. Porto Alegre: EDIPUCRS, 2002, p. 45.
} 
para o próprio Cristo. Constituído São Pedro como chefe da Igreja, ocorre a intermediação entre o próprio Cristo e os sucessores de Pedro, os Papas ${ }^{17}$.

A literatura examinada nos autoriza, portanto, a reconhecer que o episódio das bulas alexandrinas e a fundamentação jurídica da tomada das terras americanas por parte de Castela deita raízes muito mais no movimento medieval da teoria dos dois poderes e em sua leitura hipertrofiada, ao ponto de o Papa realizar uma doação, esse instrumento jurídico por excelência, de partes do globo terrestre para os reis de Castela, mediante documentos utilizados durante décadas como "justos títulos" da posse das terras americanas por parte dos castelhanos. Daí podemos traçar uma genealogia da cosmovisão que forma a eficácia desses justos títulos perante os próprios espanhóis e terceiros: é muito mais familiar à teoria política agostiniana do que ao tomismoaristotélico.

A Bula Inter Coetera utiliza ao menos dois institutos jurídicos, além de um mandato missional com exclusividade para Castela. Valendo-nos do trabalho de Rafael Ruiz, analisaremos em separado o aparecimento desses três tópicos no texto da Bula.

No que diz respeito à doação, podemos ler:

Todas e cada uma das terras preditas com a autoridade de Deus onipotente, concedida a Nós por São Pedro, como Vigário de Jesus Cristo, com todos os domínios das mesmas, com suas cidades, acampamentos militares, lugares e vilas, com todos os seus direitos e jurisdições, doamos, concedemos e damos a Vós, e a vossos herdeiros e sucessores dos Reinos de Castela e de Leão, para sempre, e com a mesma autoridade apostólica investimovos a Vós e a vossos herdeiros e sucessores como senhores das mesmas com plena, livre e absoluta autoridade. ${ }^{18}$

Além do instituto da doação, há também, animando a Bula, o do encargo, isto é, o Papa, como condição da doação, estabelece para a Coroa espanhola o encargo da missão espiritual:

Nós, louvando muito ao Senhor por esse vosso santo e louvável propósito, encorajamo-vos e requerimo-vos para que esses povos recebam a Religião Católica Cristã. E, além disso, mandamo-vos em virtude da santa obediência que (...) procureis enviar às mesmas terras firmes e ilhas homens bons, temerosos de Deus, doutos, sábios e experientes para que instruam os naturais na Fé Católica e lhes ensinem bons costumes, pondo nisso toda a diligência que convier. ${ }^{19}$

Ainda há que ser citada a exclusividade da missão: o Papa confere exclusividade aos Reis de Castela e Leão para o recebimento do encargo da empresa de evangelização, proibindo quaisquer outros reinos de se aventurarem na empresa sem a autorização dos reis castelhanos, inclusive para a prática de atividades econômicas:

E absolutamente proibimos quaisquer pessoas de qualquer dignidade, mesmo que seja Real ou Imperial, estado, grau, ordem ou condição, sob pena de excomunhão latae sententiae, de irem por causa das mercadorias ou por outra qualquer causa sem especial licença vossa ou de vossos herdeiros ou sucessores às ilhas e terras firmes descobertas ou por descobrir. ${ }^{20}$

\footnotetext{
${ }^{17}$ Cf. DOUGNAC RODRÍGUEZ, Antonio. Manual de Historia del Derecho Indiano. México, D.F.: UNAM, 1994, p. 28.

${ }^{18}$ RUIZ, Rafael, op. cit., p. 74. Rafael Ruiz utiliza, como referência para o estudo das Bulas, a obra de Venancio D. Carro, OP.

${ }^{19}$ Idem, p. 75.

${ }^{20}$ Idem, ibidem.
} 
Há nesses trechos selecionados três pontos principais que formarão a base dos questionamentos e problematizações da doutrina vitoriana a respeito da validade, da legitimidade e da ética da colonização espanhola. Tomando a Bula Inter Coetera como pano de fundo, podemos destacar então os três pontos basilares para toda a teoria de Vitoria: i) qual o fundamento de autoridade apto a sustentar a doação perpétua feita pelo Papa aos Reis de Castela e Leão; ii) se a evangelização pode ser feita com quaisquer meios, mesmo contra a vontade dos índios; iii) se o Papa tem autoridade para proibir os outros reis até mesmo de comerciarem nas novas terras descobertas ${ }^{21}$.

Há também outro documento de fundamental importância para a ética colonial espanhola antes de Francisco de Vitoria: O Requerimiento, redigido pelo jurista Juan López de Palacios Rubios, em 1513, vinte anos após as Bulas alexandrinas, que deveria ser lido para os índios antes de terem suas terras tomadas pelos conquistadores espanhóis.

O teor do documento, apesar de longo, merece ser transcrito, pois veremos novamente o fundamento medieval da teoria dos dois poderes, com um agravante adendo: este documento passa a ser lido para sujeitos que nada compreendiam da língua e cultura espanholas:

Deus, o Senhor, entregou a um homem chamado São Pedro o poder sobre todos os povos da terra, a fim de que ele fosse senhor e dominador sobre todos os homens do mundo (...) Todos the devem obediência, pois ele devia ser a cabeça do gênero humano inteiro, onde quer que vivessem ou morassem os homens, sob qualquer espécie de lei, em qualquer sorte de seita ou fé. Ele entregou-lhe o mundo como reino e domínio seu (...) [devendo] julgar e governar todas as nações cristãs, aos mouros, judeus, pagãos, e aos demais povos de qualquer seita ou fé. Chamaram-no de Papa, i.e., admirável e grande pai e dominador de todos os homens. A esse São Pedro obedeciam e honravam como senhor e rei e dominador do universo aqueles que viveram em seu tempo e, do mesmo modo, procedeu-se para com todos os que foram eleitos para o Pontificado depois dele. Ora, acontece (...) que um desses Papas doou aos reis espanhóis as ilhas e terras recém-descobertas, de modo que Suas Majestades, por força daquela doação, são reis e senhores das ditas ilhas e terras. Até agora, quase todos os aborígenes a quem foi explicada essa situação reconheceram a autoridade dos reis espanhóis e aceitaram a verdadeira fé. Suas Majestades acolheram-nos com paz e mansidão e ordenaram que fossem tratados como súditos e vassalos seus. Agora também vós sois convidados a reconhecer a Santa Igreja como senhora e dominadora do mundo inteiro e a prestar a vossa homenagem ao Rei espanhol, como a Senhor vosso. Se assim não acontecer, agiremos violentamente contra vós e obrigar-vos-emos a dobrar a cerviz sob o jugo da Igreja e do Rei, como convém a vassalos rebeldes, com a ajuda de Deus. Privar-vosemos das posses e reduzir-vos-emos a vós, vossas mulheres e filhos à escravidão. E, desde já, queremos declarar que só vós sereis culpados pelo sangue derramado e pela desgraça que cair sobre vós, não porém Suas Majestades nem estes cavaleiros que conosco vieram. ${ }^{22}$

Percebe-se, assim, as profundas raízes medievais da teoria dos dois poderes a animarem a tessitura do Requerimiento, aplicado e lido na América durante os primeiros anos da colonização espanhola.

A inovação que representou a Escola de Salamanca e a doutrina de Vitoria pode ser entendida partindo

\footnotetext{
${ }^{21}$ Idem, p. 76.

${ }^{22}$ Idem, p. 76-77. A obra utilizada por Ruiz para o exame do Requerimiento é o livro clássico de Joseph Hoffner, A Ética colonial espanhola do Século de Ouro. Cristianismo e dignidade humana. Rio de Janeiro: Presença, 1977, p. 206.
} 
desses dois documentos expostos, a Bula Inter Coetera o o Requerimiento. Com efeito, o que opera Vitoria e seus seguidores será o questionamento do fundamento dos dois documentos, qual seja, a premissa principal de que Cristo e, consequentemente, o Papa, não eram senhores do universo. Assim, os documentos jurídicos construídos a partir desse fundamento seriam eivados de vícios de validade e legitimidade. Ao longo do século XVI, em decorrência da ampla aceitação das teses de Vitoria, ver-se-á que os até então justos títulos perderão sua eficácia. Os marcadores eficaciais das teses de Vitoria e de seus discípulos da Escola de Salamanca vão sendo aferidos com base no teor das legislações que a Coroa promulga em meados do século XVI, sobretudo com as Leyes Nuevas. Os relatórios dos frades, sobretudo os que Las Casas elabora então para o imperador Carlos V, foram tão vivos que o fizeram decidir retirar seu governo das Índias e devolver o domínio aos indígenas, mas o pedido de alguns teólogos, entre eles Vitoria, aconselharam o monarca a não pôr em prática a ideia da restituição e abandono das províncias indianas, pois isto prejudicaria a cristianização dos indígenas ${ }^{23}$. Carlos $V$ não se retirou e decidiu elaborar uma nova legislação para as Índias denominada de Leyes Nuevas, promulgadas em 1542, contendo a aplicação das teses vitorianas transformadas em doutrina legal ${ }^{24}$.

Nesse momento podemos voltar à análise da relección de Vitoria de 1528, De potestate civili. Veremos que podemos remontar os argumentos vitorianos aos ensinamentos de Aristóteles, para quem o ser humano é um zoôn politikón e, neste sentido, se Vitoria se desvincula da tradição jurídica medieval, se coloca, por outro lado, sob a influência do humanismo renascentista e do resgate da tradição humanista clássica.

Logo na introdução, Vitoria fará a famosa observação acerca do ofício do teólogo, para o qual nenhum tema ou discussão lhe são alheios ou irrelevantes. Ademais, demarcará a sua relección sobre os poderes público e privado e de sua origem, tendo como base o conhecido trecho de São Paulo, "não há poder que não venha de Deus"25. Esse trecho que durante anos, na Idade Média, serviu para fundamentar a primazia Pontifícia e a submissão dos poderes seculares ao Papa, será o ponto de partida das relecciones de cariz político de Vitoria.

Vitoria inicia sua aula ${ }^{26}$, após a introdução, com a investigação das causas do poder civil ou laico, fazendo referência à Física de Aristóteles, para o qual pensamos que conhecemos algo quando conhecemos suas causas. Novamente citando a Física, dirá que há que se considerar as atividades humanas, ao lado das coisas a serem conhecidas através das causas, em relação ao fim, que é a primeira e principal das causas.

Após discorrer sobre os filósofos antigos e suas considerações sobre a matéria e a noção de necessidade e finalidade, passando por Epicuro e Lucrécio, refutará o aspecto indeterminista e contingencial da teoria do último, para defender uma verdade suprema: a de que tudo o que existe no universo foi criado por algum fim e utilidade, $\mathrm{e}$

\footnotetext{
${ }^{23}$ Cf. MARTÍNEZ-CARDÓS RUIZ, José-Leandro, op. cit., p. LI.

${ }^{24}$ RUIZ, Rafael, op. cit., p.

${ }^{25}$ Non est potestas nisi a Deo, segundo a Vulgata citada por Vitoria.
} 
que tudo o que foi feito é necessário que tenha sido feito. Assim, Vitoria parte para a investigação do fim pelo qual o poder que se está analisando na relección foi constituído, elaborando uma narrativa acerca dos aspectos distintivos do ser humano face aos outros animais. Articulará a razão, a virtude e a palavra como fatores distintivos de um ser racional e virtuoso mas, por outro lado, débil, pobre, indigente, desprovido de todo auxílio, indigente, desnudo e implume ${ }^{27}$.

Para socorrê-lo contra as necessidades e intempéries da existência, segundo Vitoria, era necessário que os homens não andassem errantes e vagando pelos desertos como feras, mas que vivessem em sociedade e se prestassem mútuo auxílio. Nesse momento, Vitoria desloca seu argumento novamente para a obra de Aristóteles, para quem sem doutrina e experiência não pode o homem perseguir a perfeição de entendimento, e que isto não se consegue de maneira alguma na solidão ${ }^{28}$. Em seguida Vitoria traz um interessante argumento que se soma ao trecho aristotélico: mais ainda, neste aspecto parece que somos inferiores aos brutos animais, porque eles podem conhecer por si mesmos as coisas que lhes são necessárias, mas os homens não podem em absoluto conhecê-las. Parece dizer Vitoria que somente um esforço coletivo pode trazer à vida o homem tal qual o concebemos. Para isso, aliás, foi o homem dotado de palavra: Aristóteles aparece novamente para fundamentar o argumento de que a palavra é a "mensageira do entendimento", e que só para esse uso nos foi dada e só por isso o homem é superior aos animais; contudo "a palavra seria inútil se o homem não vivesse em sociedade" e, se fosse possível que a sabedoria pudesse existir sem a palavra, ela seria desagradável e insociáve ${ }^{29}$. Em um movimento do qual participam a citação ao Eclesiastes ${ }^{30} \mathrm{e}$ à Política ${ }^{31}$ de Aristóteles, Vitoria reconhecerá que o homem é por natureza civil e social ${ }^{32}$.

A vontade, cujos ornamentos são a justiça e a amizade, seria "deformada e manca" fora das sociedades humanas. Assim também a justiça só pode exercer-se em uma comunidade humana. Novamente citando a Política, dirá Vitoria que na natureza nenhuma coisa ama a solidão e que somos todos levados pela natureza à comunicação ${ }^{33}$. Esse será um aspecto importante para o restante da teoria vitoriana, pois veremos que um dos fundamentos de sua revolução copernicana do direito será o chamado direito de comunicação ou ius

\footnotetext{
${ }^{26}$ É pertinente recordarmos que Vitoria jamais entregou algum material para ser impresso e divulgado. Todo o material de sua autoria ao qual temos acesso hoje são fruto de anotações de seus alunos e ouvintes em Salamanca.

${ }^{27}$ VITORIA, Francisco de. Sobre el poder civil, op. cit., p. 10.

${ }^{28}$ Vitoria cita a Ética a Nicômaco, II, 1, 1103a. Em VITORIA, F. op. cit., p. 11.

${ }^{29}$ VITORIA, F., op. cit., p. 11.

30 20, 32: "Sabedoria oculta e tesouro escondido, de que servem uma e outro?"

${ }^{31}$ Política, I, 2, 1253a.

${ }^{32}$ Cf. PENA, Javier. “Universalismo moral y derecho de gentes en Francisco de Vitoria”. In Revista de Estudios Histórico-Jurídicos, n.28. Valparaíso: 2006, pp. 289-310: "Dicho sea de paso, seguramente la gran aportación de Vitoria y Suárez no haya sido la creación del Derecho internacional, que presupone precisamente la perspectiva de un sistema de estados, difícil de concebir sobre todo en la época de Vitoria, sino la idea de un orden moral y jurídico transnacional, es decir, a través de y más allá de las entidades políticas particulares: un orden cosmopolita".

${ }^{33}$ Política, I, 2, 1253a.
} 


\section{communicationis ${ }^{34}$, que será sustentado em sua relectio De indis recenter inventis.}

O tema da aula de Vitoria é bastante ambicioso e, quiçá, só poderia mesmo ser empreendido por um teólogo. A origem das cidades e das repúblicas não seria, para ele, uma invenção dos homens e, consequentemente, não é algo a ser considerado artificial, mas brota da própria natureza, que sugeriu aos mortais humanos tal modo de vida para sua defesa e conservação. Neste sentido, se não houvesse alguém para mirar e se preocupar com o bem comum, as comunidades seriam aniquiladas e desapareceriam ${ }^{35}$.

Podemos depreender logo em seguida o paradigma organicista da doutrina de Vitoria: se não há quem governe e, por conseguinte, quem obedeça, se dissolverá o povo. A utilização da metáfora do corpo humano é neste sentido reveladora:

Do mesmo modo que o corpo humano não pode conservar-se em sua integridade se não há uma força ordenada que organize todos e cada um dos membros para a utilidade dos demais, e sobretudo para o proveito de todos os homens, isso ocorreria [a dissolução do povo], sem dúvidas, também na cidade se cada um se preocupasse só com seu próprio proveito e se despreocupasse com o bem público. ${ }^{36}$

Vitoria conclui, após este trecho, que a causa final e principalíssima do poder civil e secular é a utilidade, ou uma grande necessidade à qual ninguém pode se opor, "a não ser os deuses"37.

A concepção de Vitoria acerca da causa eficiente da potestade civil - e aqui percebemos a influência de Tomás de Aquino - é a de que essa causa seria o próprio Deus, uma vez que o poder público se constitui pelo direito natural e o autor do direito natural, por sua vez, não é outro senão Deus. Isso o permite fazer uma urdidura entre o âmbito civil e o divino ou religioso muito diferente do que até então era feito pelas correntes agostinianas e pelos partidários da teoria dos dois poderes e da soberania pontifícia, pois, aqui, ainda que a causa eficiente do poder civil seja Deus, como lá, há uma rigorosa separação entre direito divino e direito natural.

Não obstante, Vitoria é muito claro também em relação à sua preferência pela monarquia enquanto forma ideal de estruturação do poder público. Para ele, não haveria menos liberdade no principado régio do que no aristocrático e no democrático, pois, sendo um só o poder, é melhor estar submetido a um indivíduo do que a muitos, pois quando há muitos que dominam, muitos também ambicionam o poder. É forçoso reconhecer, portanto, as raízes monárquicas das formulações de Vitoria.

Ao final da primeira parte da relectio, creio que vale mencionar também um parágrafo da teoria de Vitoria sobre a guerra justa, o que ele desenvolverá melhor anos depois em sua relectio De iure belli, de 1539. A

\footnotetext{
${ }^{34}$ Cf., neste sentido, VALADARES, Jeferson da Costa. Notas sobre o humanismo jurídico de Francisco de Vitoria (ca. 1486-1546) e o ius communicationis em contexto. Niterói: 2015, no prelo. Jeferson da Costa Valadares empreende uma instigante investigação sobre a teoria de Vitoria tendo como pedra de toque o conceito de ius communicationis. Além disso, privilegia o aspecto epistemológico que embasa o pensamento do mestre salmanticense, algo imprescindível e que muito enriquece os debates sobre sua obra no contexto do humanismo renascentista sob influxos do tomismo.

${ }^{35}$ Aqui Vitoria cita Mateus, Mt 12, 25; e Lucas, Lc 11, 17: "Todo reino em si dividido será desolado".

${ }^{36}$ VITORIA, F., op. cit., p. 14.

${ }^{37}$ Idem, ibidem.
} 
guerra jamais seria justa se cometida em detrimento do proveito e utilidade para a república, ainda que houvesse títulos e razões para uma guerra justa. Há uma motivação não exposta à primeira vista que nos leva e entender nessa formulação o início do que séculos depois se sedimentou sob a forma dos direitos humanos supraestatais. Pois, com efeito, Vitoria está sustentando que, sendo uma república parte do orbe terrestre, ainda que uma guerra seja útil para uma república mas nociva para o restante do orbe "ou para a cristandade", tal guerra deve ser considerada injusta. O conceito de cristandade já funciona como um fiador do reconhecimento de "algo a mais" em cada sujeito para além de seu pertencimento a cidades, reinos e províncias específicas. Esse "algo a mais", supraestatal e criador de uma identidade que, na época de Vitoria, espalhava-se por todo o mundo, acaba sendo absorvida pela formulação anterior, mais universalista, ou seja, a de que cada república faz parte do orbe terrestre. Entendemos aqui que Vitoria se refere não apenas às repúblicas que compõem a cristandade, mas refere-se às outras religiões e povos, sobretudo os índios americanos.

Podemos notar, nessa formulação de Vitoria, a urdidura de duas linhas que formam sua doutrina: a ética cristã, que enxerga uma comunidade para além dos Estados e províncias, a Cristandade ou Respublica Christiana; a causa eficiente do poder civil residindo em Deus, continuando a tradição tomista; e, também, a profunda influência do humanismo que aflorava no Renascimento, num resgate de pensamentos e obras de importantes autores clássicos greco-romanos, como Aristóteles e Cícero, só para citar duas das suas principais influências. Aristóteles e Cícero que, em suas obras, sustentam uma teoria sobre o ser social universal, pois ambos compartilham da mesma cosmovisão de Vitoria, isto é, a de que a razão advém da natureza e, daí, também a inclinação humana a viver em comunidade. Vejamos um extrato de Cícero, quando afirma, no De legibus, que a justiça advém da natureza:

Mas de todo o material das discussões filosóficas, certamente nada há de mais valioso do que a plena realização de que nós nascemos para a Justiça, e esse direito está baseado, não sobre as opiniões humanas, mas sobre a Natureza. Este fato ficará imediatamente compreensível se houver uma clara concepção da amizade humana e união entre os homens. Nada é tão comum, tão exatamente assemelhado, como todos nós somos uns com os outros (....). Assim, qualquer que seja a definição do que seja o homem, uma só vale para todos. ${ }^{38}$

Com isso, Vitoria procura marcar que o Estado é uma comunidade derivada da sociabilidade natural humana, cujo fundamento é a natureza. Essa formulação, apesar de simples e ter sido já exposta por Aristóteles há muito tempo, foi uma revolução copernicana para a teologia política e para o direito no limiar da Modernidade pois, assim, Vitoria rompeu com as teses do Império e da Igreja de então, além de delimitar o poder indireto da potestade eclesiástica. Em seu Comentário crítico às relecciones vitorianas, Martínez-Cardós Ruiz afirma ter Vitoria chamado a tese do domínio temporal do Papa sobre o mundo e os príncipes de "mera invenção para

\footnotetext{
${ }^{38}$ CÍCERO, Marcus Tullius. De Legibus, I, X, 28-30. Cambridge: Harvard University Press, 1928.
} 
adular e lisonjear aos pontífices" ${ }^{39}$.

Sustentou Vitoria que o Estado, enquanto derivado de uma sociabilidade humana natural, seria o centro irradiador do poder, e não diretamente em Deus ou nas vontades individuais (tese do contratualismo). Há na teoria de Vitoria sutis contornos que a diferenciam tanto de uma teoria teocrática quanto do futuro contratualismo iluminista. Assim, a intepretação da origem do poder defendida por Vitoria orientou eticamente os processos políticos, além de prevenir riscos de despotismo e conferia uma participação do povo no governo. Interessante notarmos que essa teoria surge quase simultaneamente com o Estado moderno de feições absolutistas - pouco depois Jean Bodin sustentaria novamente a tese da fundamentação divina no poder. Mas atentemos para o fato de que a teoria de Vitoria possuiu o condão de pavimentar o caminho para, partindo de uma base teórico-ontológica segura sobre o ser humano, facilitar o desenvolvimento da ciência jurídica e dos ordenamentos jurídicos modernos. Neste sentido, podemos ver nos desenvolvimentos doutrinários posteriores da relectio uma série de proto-questões de suma relevância para o direito moderno, como, por exemplo, se as leis civis obrigam os legisladores, ao que responde positivamente, e questões envolvendo direito e moral ou autonomia e heteronomia, quando se perguntará se as leis e constituições obrigam somente no foro contencioso ou no da consciência. Em resumo: há uma série de desdobramentos que põem em jogo sutilezas a respeito das filigranas dessa comunidade de animais políticos, cujos efeitos por sua vez se desdobrarão sobre a modernidade. E assim, ao iniciar um movimento intelectual rumo a uma teologia moral e política em prol de Aristóteles e contra Alexandre VI, podemos passar ao exame das relecciones posteriores, com a devida fundamentação.

\section{A LIBERDADE NA RELECTIO DE INDIS PRIOR}

A conferência De indis prior está dividida em três partes: a primeira tratará sobre a capacidade de os índios terem domínio sobre seus bens e terras, bem como sobre a autoridade adequada para tratar questões que gerem dúvidas; a segunda parte irá tratar dos títulos ilícitos evocados pelos espanhóis para o domínio dos índios e de suas terras; a terceira parte irá tratar de títulos lícitos, no entender de Vitoria, para que esse domínio possa ocorrer com lisura e justiça.

Partindo do ius communicationis como fundamento do poder civil, de acordo com a conferência dada dez anos antes De potestate civili, desenvolveremos o percurso que Vitoria procura fazer nessas três partes do De indis prior da seguinte maneira: i) ius communicationis; ii) capacidade dos bárbaros para ter o domínio sobre seus bens e terras por direito natural e de gentes; iii) ius missionis, ou o fundamento de circulação dos espanhóis pelos domínios dos bárbaros, ligando assim a ponta do final com a do início, formando uma circularidade, algo

\footnotetext{
${ }^{39}$ MARTÍNEZ-CARDÓS RUIZ, José-Leandro, op. cit., p. LXI.
} 
que denota a engenhosidade de Francisco de Vitoria ${ }^{40}$.

A primeira parte do De indis prior tem dois eixos principais: a questão das matérias duvidosas e quem estão aptos a examiná-las e respondê-las e a questão da capacidade dos bárbaros para ter domínio público e privado.

Abrindo a conferência com a problemática das matérias duvidosas, Vitoria buscará dar embasamento para o ulterior deslinde de sua exposição. A atenção de Vitoria aqui é defender a importância da opinião dos expertos e doutos teólogos sobre as leis divinas e humanas e, assim fazendo, construir uma espécie de microssistema voltado para a segurança jurídica. Talvez devido aos ventos do protestantismo, Vitoria é severamente contrário ao livre exame individual de questões ditas duvidosas atinentes a licitude ou ilicitude de assuntos ligados à religião e ao direito sem passar pelo crivo da autoridade de um especialista, neste caso, um teólogo. Por exemplo: se alguém, sem aconselhar-se com um entendido, fizesse um contrato de cuja licitude normalmente gera dúvidas, pecaria sem dúvidas, inclusive se o contrato fosse lícito, mas não fundado na autoridade de um especialista mas apenas em sua própria inclinação ou critério ${ }^{41}$. Em outro exemplo, se alguém, duvidando de que uma mulher fosse sua esposa, consulta aos doutores se está obrigado ou está permitido dar ou exigir o débito conjugal, e respondessem que de nenhuma maneira é lícito, ele, não obstante, levado pelo carinho ou paixão, não lhes dá crédito e pensa que é lícito, certamente pecaria tendo relações com ela, ainda quando para ele fosse lícito, porque obraria contra a consciência a que deveria atentar-se ${ }^{42}$.

Assim Vitoria faz uma divisão entre o foro contencioso, em que está obrigado o juiz de acordo com o alegado e o provado, e o foro da consciência, no qual há obrigação de julgar não segundo o próprio parecer, mas de acordo com motivos de probabilidade ou de autoridade dos entendidos, do contrário o juízo é temerário e se expõe ao perigo de equivocar-se. Aqui vemos a raiz do que será chamado de communis opinio doctorum, a opinião comum dos doutores. É em verdade uma área que aqui começa a se formar em torno de questões ligadas à consciência, culpa, confissões, etc., que será aos poucos sendo ocupada pelo direito, pela moral e, posteriormente, também pela psicologia, ao passo que a teologia vai sendo desalojada. Mas na época de Vitoria a teologia era omnidisciplinar e a orientação das consciências uma de suas principais funções, oriunda de processos de reformulações e constante disciplinamento, indo desde entendimentos acerca das questões duvidosas,

\footnotetext{
${ }^{40} \mathrm{O}$ ius communicationis, em verdade, traz uma gama de significados possíveis. Gostaríamos de propor aqui no mínimo dois principais, retomando o trabalho de Jeferson da Costa Valadares. Teríamos, portanto, i) o ius communicationis como matéria precípua sem a qual não haveria sociedade: "A ideia de um ius communicationis deriva, certamente, na sua acepção semântica, do conceito de communicatio. O que é communicatio? É a ação de comunicar, de fazer parte de; tem ainda um sentido de comunidade [...]" e ii) um aspecto ético em relação ao outro, estrangeiro, seja um outro cristão ou "bárbaro", com desdobramentos jurídicos em um sistema global: "[o ius communicationis] estabelece, grosso modo, o direito de imigração e hospedagem e livre circulação de estrangeiros em terras, desde que de forma pacífica e respeitosa". Duas acepções cuja diferença, embora sutilmente interligadas, nos parece importante marcar. Cf. VALADARES, Jeferson da Costa. op. cit.

${ }^{41}$ VITORIA, Francisco de. Op. cit, p. 62 e ss.
} 
passando pela importância do monopólio da confissão para a regulação e influência sobre as massas de camponeses analfabetos.

Ademais, o poder sobre a consciência acaba fundando uma instância importante do psiquismo humano, numa evolução perceptível ao menos de maneira sistematizada desde a psicologia aristotélica, que dará origem à entrada da noção de consciência no direito, sobretudo no direito civil e penal (noções como culpabilidade, dolo, etc.), até a fundação da moderna disciplina da psicologia. Vitoria aqui já trabalha com esquemas hermenêuticos característicos da teologia mas claramente observáveis posteriormente no direito, como as noções de ignorância vencível e invencível e pecado mortal e venial. Haveria portanto uma gradação das ações com base em esquemas hermenêuticos segundo os quais, aqui, pecar mortalmente seria mais grave do que venialmente, e cuja eficácia e funcionamento ficaria a cargo dos ditos expertos.

Aqui ainda não se fala em segurança jurídica mas em segurança de consciência. Assim, pois, para Vitoria, em matéria duvidosa há obrigação de consulta àqueles aos quais corresponde o exame do caso. Se, uma vez consultada a dúvida, houvesse parecer de ilicitude por parte dos doutos, era obrigatório seguir o parecer, mesmo que na realidade a matéria posta em exame fosse lícita. Em contrário, uma vez consultada a dúvida houvesse sentença de que fosse lícito, quem segue a opinião dos sábios obraria com segurança, inclusive no caso de ilicitude real da matéria. A importância e o peso dos pareceres dos doutores teólogos era, portanto, total. Após fazer essas colocações, Vitoria volta ao exame da problemática dos índios. Se aquele assunto era tratado em grande parte por homens doutos e honestos, era crível que o exame se fizesse com retidão e justiça. Há um trecho que não pode deixar de lembrar da obra de Las Casas:

Como, por outro lado, ouvimos falar de tantas matanças e espoliações de homens inofensivos, de tantos senhores despojados de suas posses e domínios particulares, se pode duvidar com razão se tudo isso foi feito com direito ou com injustiça. Assim, pois, essa discussão não parece de todo inútil (.... ${ }^{43}$

Vitoria, a seguir, procura construir um entendimento de uma espécie de monopólio da teologia para o exame e julgamento das questões envolvendo os índios, visto que eles não seriam um assunto para os juristas pois, não estando submetidos ao direito humano, seus assuntos não podem ser analisados pelas leis humanas, mas pelas divinas. Por isso os juristas não seriam suficientemente competentes para examinar essas questões, em detrimento dos teólogos. Além disso, como a maioria dos assuntos trata do foro da consciência, corresponde dar a palavra aos sacerdotes, isto é, à Igreja. Por isso, diz Vitoria, "se manda no Deuteronômio que o rei receba das mãos do sacerdote um exemplar da lei" ${ }^{44}$.

Avançando, Vitoria se pergunta se os bárbaros, antes da chegada dos espanhóis, eram verdadeiros donos,

\footnotetext{
${ }^{42}$ Idem, ibidem.

${ }^{43}$ Idem, p. 65.

${ }^{44}$ Idem, p. 66.
} 
tanto privada quanto publicamente, das coisas e das posses privadas, e se havia entre eles príncipes e senhores. Entrará, pois, numa discussão entre duas opiniões muito em voga na época: a de que ou os índios eram servos por natureza, com base em Aristóteles e, posteriormente, defendida por Gines de Sepúlveda em Valladolid, em 1550, em disputa contra ninguém menos que Las Casas, que defende a posição oposta, a mesma de Vitoria. Com efeito Vitoria sustentará que os índios estavam sob o domínio pacífico de seus bens e possuíam certa ordem pública. Irá construir o argumento segundo o qual deve-se distinguir questões de fé (o caso de os índios, assim como os sarracenos e os judeus, serem infiéis) com questões jurídicas, como o domínio. Dessa maneira, seria ilícito despojar os sarracenos e os judeus de seus bens assim como aos índios. Vitoria chega mesmo, e aqui evidentemente essa hipótese há de ser lida com um grão de sal, a lançar as bases para a futura antropologia e etnologia, quando, ao discorrer sobre a capacidade de os bárbaros serem verdadeiros donos, irá dizer: "no son dementes sino que a su manera tienen uso de razón. Está claro, porque tienen cierto orden en sus cosas, uma vez que poseen ciudades establecidas ordenadamente, y tienen matrimonios claramente constituidos, magistrados, señores, leyes, artesanos, mercaderes, cosas todas ellas que requieren el uso de razón; asimismo tienen una espécie de religión, no yerran en cosas que son evidentes para los demás, lo cual es indicio de uso de razón” ${ }^{45}$.

Assim os índios eram senhores verdadeiros, pública e privadamente, antes da chegada dos espanhóis, o que os coloca no sistema-mundo em condições de igualdade com os muçulmanos e os judeus, enquanto povo infiel mas portador de razão e apto para a troca comercial ${ }^{46}$. Para fechar essa primeira parte da conferência, Vitoria enfrenta uma das questões mais espinhosas da época, sobre serem os índios servos por natureza. Em uma argumentação cristalina, o frade dominicano irá estabelecer uma interpretação de Aristóteles no sentido de que o Estagirita não estaria se referindo neste trecho da Política ao fato de que os faltos de engenho seriam servos por natureza e não teriam domínio nem de si nem de suas coisas, mas estaria se referindo à necessidade que uns, com menos engenho, têm de ser dirigidos por outros, mais inteligentes, que se sobressaem em virtude dessa inteligência, algo que poderia denotar que por natureza haveria uma faculdade de mandar e dirigir, mas não um mando sobre outros através de títulos que eliminassem a capacidade geral para o domínio, voltada para o âmbito civil.

A segunda parte do De indis priortratará dos títulos ilegítimos pelos quais os bárbaros do Novo Mundo

\footnotetext{
${ }^{45}$ Idem, p. 82.

${ }^{46}$ Neste sentido, se considerarmos o projeto da Escolástica salmanticense como um todo orgânico, como é nossa proposta, extrairemos daí que o ius communicationis permite um mandato missional e apostólico cristão no mundo, o que se desdobraria num projeto mundial de conversão. Cf., neste sentido, COLOMBO, Emanuele. "Infidels at Home': Jesuits and Muslim Slaves in Seventeenth-Century Naples and Spain”. In Journal of Jesuit Studies, v. 1, n.2, Leiden: 2014, pp. 192-211: "The problem of language, a key issue in the Jesuit missions overseas, was also raised in the missions to Muslim slaves. In Naples, Jesuits soon realized that it was necessary to master Arabic to effectively communicate with the slaves. The importance of studying Arabic was not new in the Society of Jesus. Ignatius had planned different projects — most of which were never realized — to create Arabic speaking
} 
estiveram sob o poder dos espanhóis. Vitoria elencará sete títulos e em muitos aspectos de sua argumentação retomará motivos da conferência anterior, De potestate civili. Os títulos elencados como ilegítimos são:

1. "O imperador é o senhor do mundo"

2. "A autoridade do Sumo Pontífice"

3. "Direito de descobrimento"

4. "Que se negam a receber a fé de Cristo, não obstante ter-se lhes rogado insistentemente que a aceitem"

5. "Os pecados dos bárbaros"

6. "Por eleição voluntária"

7. "Uma especial doação de Deus"

Vitoria refutará um a um os referidos títulos, todos com suposto potencial de embasamento do domínio espanhol sobre os índios. Estes títulos, de modo geral, não seriam idôneos e a estratégia de Vitoria é a de esvaziar o poder soberano do Sumo Pontífice e, em questões de costumes, aproximar os índios dos espanhóis e europeus, ao dizer, por exemplo, que não seria lícito ao Papa fazer a guerra contra os cristãos por motivo de serem fornicadores ou ladrões, nem sequer por serem sodomitas, nem tampouco por esses motivos se lhes poderiam confiscar as terras e bens e dar-se lhes a outro príncipe, como costumava ocorrer com os índios.

A noção de liberdade ou livre-arbítrio apresenta-se como fundamental no argumento de Vitoria: nesse sentido podemos remontar à noção tomista de liberdade embutida na aceitação da fé (II-Ilae, q.10, a. $8^{47}$ ) que estará presente em Vitoria e em Las Casas ${ }^{48}$. Isto quer dizer que, mesmo que os índios se neguem a receber a fé de Cristo, não é legítimo que sejam turbados em suas posses e sofram violência física por meio de agressões e guerras por parte dos cristãos. Não obstante, em virtude do ius communicationis, a circulação de ideias e pessoas em terras indígenas deve ser plenamente assegurada. Assim, temos o cenário em que, se de um lado cabe ao cristão utilizar de todos os meios para a persuasão tolerante do indígena em direção à aceitação da fé cristã, este seria dotado de pleno livre-arbítrio para aceitá-la. Não haveria espaço para a coação física que o obrigasse a abraçar a fé cristã, tampouco retaliação por sua não aceitação. O ius communicationis, seria, por outro lado, o constructo que permitiria a livre circulação de pessoas e ideias pelo orbe terrestre, de onde se extrairia o mandato missional e apostólico cristão e a consequente faculdade de persuasão dos índios para a aceitação de sua fé.

colleges in order to promote Jesuit missions in North Africa. Later, the Roman College introduced the teaching of Arabic as well as a printing press with Arabic type".

${ }^{47}$ AQUINO, Santo Tomás de. Suma de Teología. Parte II-II (a). Madrid: BAC, 1990.

${ }^{48}$ Conferir, neste sentido, a tese de doutorado de NEVES, Marcelo OP. A tolerância nos limites do cristianismo católico de Frei Bartolomé de Las Casas. Tese de Doutorado apresentada ao Departamento de Filosofia e Ciências Humanas da Universidade Estadual de Campinas, Unicamp, 2006, p. 218-219: “La cual (a pregação e a fé), si recibir no quisieren, no les pueden compeler ni ejercitar sobre ellos violencia, ni dar pena alguna, porque Cristo no dejó mandato más de que se predicase y enseñase y manifestase su Evangelio a todas las gentes, y que quedase a la voluntad de cada uno creer o no creer, si quisiere" (tratado comprobatorio del imperio soberano. Idem., 524 Grifo nosso)". 


\section{CONSIDERAÇÕES FINAIS}

De forma sumária, resumimos nesta seção o que foi levantado ao longo do artigo:

i) ao trabalharmos com o conceito de poder civil na obra de Francisco de Vitoria, principalmente na relectio De potestate civili, de 1528, chamamos atenção para o fato de Vitoria ter como principal marco teórico a obra de Aristóteles e a noção de comunidade humana natural. No interior dessa noção de comunidade natural humana, temos a construção de que o humano se constitui em comunidade e por intermédio da palavra, transmissora do entendimento coletivo sobre as coisas. O ius communicationis se fundamenta na afirmação de que "somos todos levados por natureza à comunicação"; ii) o conceito de ius communicationis seria com efeito inovador na fundamentação dos contornos colonizadores da Coroa espanhola. Assim, os espanhóis, em virtude desse entendimento, enquanto membros da comunidade humana universal, poderiam circular livremente pelos domínios dos índios (aqui já embutimos o entendimento de Vitoria de que os índios seriam capazes de serem donos de seus domínios tanto no âmbito privado quanto no público), da mesma maneira que um índio poderia circular pelos domínios espanhóis e um espanhol pelos domínios franceses, e vice-versa. O trabalho missional e apostólico espanhol em terras indígenas, se por um lado poderia ser exercido livremente, por outro se limitaria pela aceitação da fé católica por parte do índio: nesse sentido incide o conceito de liberdade na aceitação da fé, conforme Tomás de Aquino na Summa Theologiae, II-IIae, q.10, a.8. Uma comissão ou mandato missional católico, certamente: mas limitado pela própria liberdade dos povos indígenas. Algo que, a nosso, ver, seria uma espécie de garantia para a busca do bem público por parte dos religiosos, para além da violência que até então se exercia pela Coroa espanhola.

Gostaríamos de marcar, por fim, que a obra de Vitoria, de cariz aristotélico, ao constituir-se tendo como referência o tímpano ${ }^{49}$ do ius communicationis, tornou-se apta para fundamentar a circulação de ideias e pessoas para o Novo Mundo. Vitoria argumentará aqui pela via seja do direito de gentes, evocando as Institutas de Gaio, o célebre trecho "o que a razão natural estabeleceu entre todas as gentes se chama direito de gentes", recepcionado por Tomás de Aquino e pelos escolásticos ibéricos, seja pela via do direito natural como uma manifestação sensível do direito divino. Neste sentido, entendemos que haveria aí já uma possibilidade de fundamentação dos direitos humanos modernos.

\footnotetext{
49 Temos aqui em vista ambos os sentidos do termo: o sentido arquitetural, no qual o tímpano aparece nas catedrais medievais sobre o portal de entrada, em forma triangular ou em arco, dentro do qual são esculpidas imagens; seja no sentido anatômico, no qual a membrana timpânica aparece como portadora da função de converter os sons da vibração do ar, originado no aparelho fonador humano, transmitindo-os aos ossículos do ouvido, em uma sofisticada operação sobre as vibrações.
} 


\title{
THE MODERN FORMS OF HUMAN RIGHTS IN FRANCISCO DE VITORIA
}

\begin{abstract}
This paper will attempt to show that there is a moral and juridical fundamentation in the Francisco de Vitoria's theory to what is called "human rights". For instance, Francisco de Vitoria, rather than build up a system for dominance, congregated the American native communities based upon the christian ethics, with an universalist characteristic. The argument will be constructed concerning the notions of civil power, liberty and free circulation and communication. When linking these elements, we will try to show that Vitoria was capable to create an avantgarde conception of ethics and of International Law, directly questioning the way through wich was constructed the Spanish colonization of America in that time.
\end{abstract}

Keywords: Renaissance. Humanism. Human rights. American spanish colonial period. Francisco de Vitoria.

\section{REFERENCIAS}

ANDRADE DA SILVA, Dinair. Tensões entre Castela e Portugal a propósito dos descobrimentos atlânticos: um estudo das bulas alexandrinas. Anais Eletrônicos do IV Encontro da ANPHLAC. Salvador, 2000. Acesso em 26 de agosto de 2015 .

AQUINO, Santo Tomás de. Suma de Teología. Trad. Ovidio Calle Campo e Lorenzo Jiménez Patón. Parte II-II (a). Madrid: BAC, 1990.

ARISTÓTELES. Política. Trad. Mário da Gama Kury. Brasília: Editora da UnB, 1997.

BEUCHOT, Mauricio. El primer planteamiento teológico-jurídico sobre la conquista de América: John Mair. Ciencia tomista. Salamanca, 1976, núm. 103, pp. 213-230

BEUCHOT, Mauricio. La polémica de la guerra de Conquista en relación con México, pp. 147-156. In BATAILLON, G.; BIENVENU, G.; GOMEZ, A. V. (Org.). Las teorías de la guerra justa en siglo XVI y sus expresiones contemporáneas. México D. F.: Centro de estudios mexicanos y centroamericanos, 1998.

CÍCERO, Marcus Tullius. De Legibus, I, X, 28-30. Cambridge: Harvard University Press, 1928.

COLOMBO, Emanuele. "Infidels at Home: Jesuits and Muslim Slaves in Seventeenth-Century Naples and Spain”. In.: Journal of Jesuit Studies, v. 1, n.2, Leiden, 2014, pp. 192-211

DOUGNAC RODRÍGUEZ, Antonio. Manual de Historia del Derecho Indiano. México, D.F.: UNAM, 1994.

GILSON, Étienne. A filosofia na idade média. Trad. Eduardo Brandão. 3a ed. São Paulo: Martins Fontes, 2013.

NEVES, Marcelo OP. A tolerância nos limites do cristianismo católico de Frei Bartolomé de Las Casas. Tese de Doutorado apresentada ao Departamento de Filosofia e Ciências Humanas da Universidade Estadual de Campinas, Unicamp, 2006.

OLIVEIRA e Silva, Paula; CALVÁRIO, Patrícia. A fundamentação, natural ou positiva, do direito das gentes em 
alguns comentários seiscentistas à Suma de Teologia de Tomás de Aquino II-Ilae, q. 57, a.3. In.: Aquinate, n. 14, Niterói, 2011, pp. 31-50

PEÑA, Javier. Universalismo moral y derecho de gentes en Francisco de Vitoria. In.: Revista de Estudios Histórico-Jurídicos, n.28. Valparaíso, 2006, pp. 289-310

PICH, Roberto Hofmeister. Dominium e ius: sobre a fundamentação dos direitos humanos segundo Francisco de Vitoria (1483-1546). Teocomunicação, v.42, n. 2. Porto Alegre, 2012, pp. 376-401.

REALE, Giovanni; ANTISERI, Dario. História da filosofia: patrística e escolástica, v.2. Trad. Ivo Storniolo. $4^{a}$ ed. São Paulo: Paulus, 2003.

RUIZ, Rafael. Francisco de Vitoria e os direitos dos índios americanos. Porto Alegre: EDIPUCRS, 2002.

SCHMITT, Carl. Teología política. Cuatro ensayos sobre la soberanía. Buenos Aires: Struhart \& Cía, s.d.

VALADARES, Jeferson da Costa. Notas sobre o humanismo jurídico de Francisco de Vitoria (ca. 1486-1546) e o ius communicationis em contexto. In.: Anais do 50 Seminário Interdisciplinar em Sociologia e Direito, Niterói, 2015, no prelo.

VITORIA, Francisco de. Sobre el poder civil. Sobre los índios. Sobre el derecho de la guerra. Trad. Luis Frayle Delgado. Madrid: Tecnos, 2012.

Trabalho enviado em 21 de março de 2016.

Aceito em 09 de maio de 2016. 